\title{
Unsustainable varieties of capitalism along the Thailand-Malaysia border? The role of institutional complementarities in regional development
}

\author{
Edo Andriesse • Guus van Westen
}

Published online: 26 September 2008

C The Author(s) 2008. This article is published with open access at Springerlink.com

\begin{abstract}
This contribution aims to couple national institutional complementarities to issues of regional development and long-term sustainability in Southeast Asia's non-core regions. A comparison is made of Satun in Southern Thailand and Perlis in Northern Malaysia. Based on fieldwork data, the findings reveal that Malaysian institutional complementarities result from a key role of the state, leading to potentially ineffective forms of economic activity. On the Thai side, institutional complementarities give free reign to entrepreneurs, but they are less conducive for inclusive regional development and addressing environmental concerns. Based on the case studies, findings of a more general applicability highlight two additional issues. First, balanced regional development requires a set of institutional complementarities that integrates economic growth with distributional strategies. Second, more attention should be paid to the adaptability of institutional arrangements as they may actually "lock in" regions in an unsustainable development trajectory in the long run, be it in economic, social or ecological terms.
\end{abstract}

Keywords Institutional complementarities · Regional development - Thailand · Malaysia

Institutional frameworks have been recognised as an important factor in the explanation of geographical variations in economic performance, complementing classical notions of comparative advantages (Lane \& Myant, 2007; Peng \& Delios, 2006; Whitley, 1999; Harriss, Hunter, \& Lewis, 1995). The varieties of capitalism

\footnotetext{
E. Andriesse ( ()

International College, Khon Kaen University, Khon Kaen 40002, Thailand

e-mail: e.andriesse@gmail.com

G. van Westen

Urban and Regional research centre Utrecht (URU), Utrecht University, P.O. Box 80115, 3508 TC

Utrecht, The Netherlands

e-mail: g.vanwesten@geo.uu.nl
} 
approach, as elaborated by Hall and Soskice (2001), has introduced the analytically powerful concept of institutional complementarity: the simultaneous, interdependent and enabling character of bundles of two or more institutional arrangements that in themselves yield specific comparative advantages and thus steer entrepreneurship, firm performance and economic development in a certain direction. Research in Southeast Asian capitalist systems has also taken root in the last decade (for instance Haggard, 2004; Doner, Ritchie, \& Slater, 2005; Barlow, 1999). This article builds on this line of work, with explicit attention to the sub-national level.

The aim of this contribution is twofold. First, we take the discussion of institutional complementarities to the level of highly similar regions belonging to different countries, in a comparative empirical investigation of the economies of two peripheral regions: that of Satun, a province of Thailand, and the neighbouring Malaysian state of Perlis. These areas have a similar physical geography, the majority of their populations is composed of Muslims of Malay descent, and both regions shared a common history until a century ago. In 1909, the international border was drawn between Thailand and what is now Malaysia, separating Satun from Perlis. ${ }^{1}$ Since then, both regions have experienced different economic trajectories that can essentially be explained by their belonging to two markedly different national contexts. How have these differences impacted on regional economic development and firm performance characteristics, and to what extent can these be related to institutional complementarities "on the ground," (i.e., in the specific contexts of Perlis and Satun)? Second, beyond the specific cases of Perlis and Satun analysed here, we will discuss the more general implications of our findings for regional development in non-core regions of Asia. What is the role of institutional complementarities in economic performance? What perspectives do different models of management and governance offer? We will specifically consider distributional aspects as well as longer-term sustainability.

The next section introduces the institutional approach in Southeast Asia, taking the varieties of capitalism (hereafter $\mathrm{VoC}$ ) approach as a starting point, but proposing some amendments. This is followed by a brief discussion of methodology issues in which the Thai and Malaysian institutional complementarities are also introduced. Then, the specific characteristics of the two regions' institutional frameworks are analysed by means of a comparison of two industries that characterise economic activity in the two study regions: Satun's seafood industry, and Perlis's construction and real estate industry. The discussion of findings will then aim at deriving conclusions of a more general applicability.

\section{National institutional complementarities in Southeast Asia}

The VoC approach asserts that firms are the central organisations within each capitalist system. Hall and Soskice (2001) argue that in order to develop and coordinate core

\footnotetext{
${ }^{1}$ During the Second World War the Japanese briefly transferred control over Perlis to the Thai government. Perlis became a Malaysian State in 1957 when Malaysia gained independence from the British.
} 
competencies, firms must maintain relationships within five institutional spheres: industrial relations, vocational training and education, corporate governance, interfirm relations and coordination vis-à-vis their own employees. Thus, each firm operates in a complex environment with many institutional relationships, either formal or informal. ${ }^{2}$ Furthermore, the five spheres, or particular sets of institutional relationships, are closely interconnected. One type of relationship in one sphere calls for a corresponding arrangement in other spheres in order to be effective. Hall and Soskice (2001) have termed these sets institutional complementarities. Such complementarities are responsible for comparative institutional advantages and ultimately specific varieties of capitalism.

It is regrettable that the VoC approach tends to focus exclusively on the dichotomy between liberal market economies (LMEs), such as the USA and Britain, on the one hand, and coordinated market economies (CMEs), of which Japan and the "Rhineland" European economies are the best-known examples, on the other (Allen, 2004). Revealing the Western bias in much of the literature on economic systems, Tickell and Peck (1995) stereotyped Malaysia and the Philippines as cases of "primitive taylorism," notable for "taylorist labour processes with almost endless supply of labour, bloody exploitation, huge extraction of surplus value, coupled with the presence of dictatorial states and high social tension." ${ }^{\prime 3}$ Such statements do little justice to the specifics and the diversity of Asian economic systems, suggesting (perhaps unwittingly) that the non-Western world is an undifferentiated set of substandard and generally deficient institutional arrangements, vaguely but inadequately reflecting the models of the part of the world that counts.

Therefore, in addition to considering the institutional spheres of the $\mathrm{VoC}$ approach we aim to address two crucial issues in this study. Although the $\mathrm{VoC}$ approach considers economic power, it neglects political power, often viewed as highly relevant in Southeast Asian capitalist systems (Haggard, 2004; Gomez, 2002; Barlow, 1999). Leading economist Pranab Bardhan convincingly argues for the inclusion of political power in institutional economic analyses. In his view, power relations matter especially for understanding the distributive effects of institutions. Disabling institutions often survive because they serve the interests of those powerful enough to change them (Bardhan, 2005: 27-86). Land rights are a classic example of institutional inertia due to power configurations. According to Carney (2004), commenting on the difficulties of industrial restructuring after the Asian financial crisis, "economic power has concentrated in the hands of a small number of politically connected incumbents who are in a position to perpetuate their elite positions and frustrate the entry of new agents into the economy." Elsewhere, Schmidt (2003) has incorporated political power in her elaboration of the $\mathrm{VoC}$ approach. She identified at least three varieties of capitalism: market capitalism

\footnotetext{
${ }^{2}$ Here we follow North (1991): "Institutions are the rules of the game in society or, more formally, the humanly devised constraints that shape human interaction. Institutions are generally divided into formal and informal institutions. Formal institutions are economic, political (and judicial) rules and contracts; informal institutions are informal codes of conduct, norms of behaviour and conventions." Thus North clearly separates institutions from organisations.

${ }^{3}$ See Bain et al. (2002) for a contemporary study of taylorism.
} 
(similar to LMEs), managed capitalism (similar to CMEs) and state capitalism in which firms and governmental authorities are the key organisations. Schmidt introduced state capitalism to conceptualise French institutional complementarities between the 1950s and 1970s. In the Southeast Asian context, Jayasuriya (2004, 2003) stated that domestic coalitions between economic and political actors and politically motivated side payments to less-favoured parts of the society comprise essential components of each national institutional framework. In sum, empirical institutional research in Southeast Asia certainly requires the inclusion of the political dimension, especially if one also wishes to derive policy implications. Moreover, power is important in analysing the position of peripheral regions within national (and global) space economies, as in our case.

Besides the neglect of political power, a further aspect unaccounted for in the VoC approach is the often personal approach to conducting business that prevails in many developing countries. Carney and Gedajlovic (2001) have thus distinguished personal capitalism, in which ownership and control of firms are combined, while business links and firm configurations are often patterned on kinship relations. Many of Southeast Asia's major companies are conglomerates whose growth trajectories are based on personal capitalist characteristics. And many of these conglomerates were founded by ethnic Chinese (Gomez \& Hsiao, 2003; Mackie, 1999; Suehiro, 1989). From the preceding discussion it is evident that capitalist systems can be analysed in several ways. This article proposes to embrace Hall and Soskice's concept of institutional complementarities, but without their singular distinction of an LME-CME dichotomy. Instead our theoretical approach combines Schmidt's (2003) typology of market, managed and state capitalism and Carney and Gedajlovic's (2001) notion of ownership and control and it takes into account the political dimension of institutional arrangements (Bardhan, 2005; Jayasuriya, 2004, 2003).

\section{Setting up the empirical cases}

This contribution is concerned with the role of institutional complementarities in shaping economic development in peripheral regions of Thailand and Malaysia. The Thai-Malaysian border area (Figure 1) offers a promising setting for a comparative study on the role of institutional frameworks as it allows us to some extent to control for local factors. While we accept that no two regions in the world are identical, their physical geography, historical patterns and population characteristics are sufficiently similar to assume that divergence between the two regions since their separation in 1909 is likely the result of differences in the national frameworks in which they have been incorporated. Our hypothesis is, then, that this difference in national context entails different institutional conditions, encouraging specific directions of economic development in each region, while discouraging others. Most of these steering institutional complementarities are likely to be defined at the national level, but of course some may actually be locally embedded. In this respect Schamp (2003) has argued that the debate on the spatial boundaries of economic institutions has just begun and hence, it is highly plausible to include national institutions in analyses of regional development. 


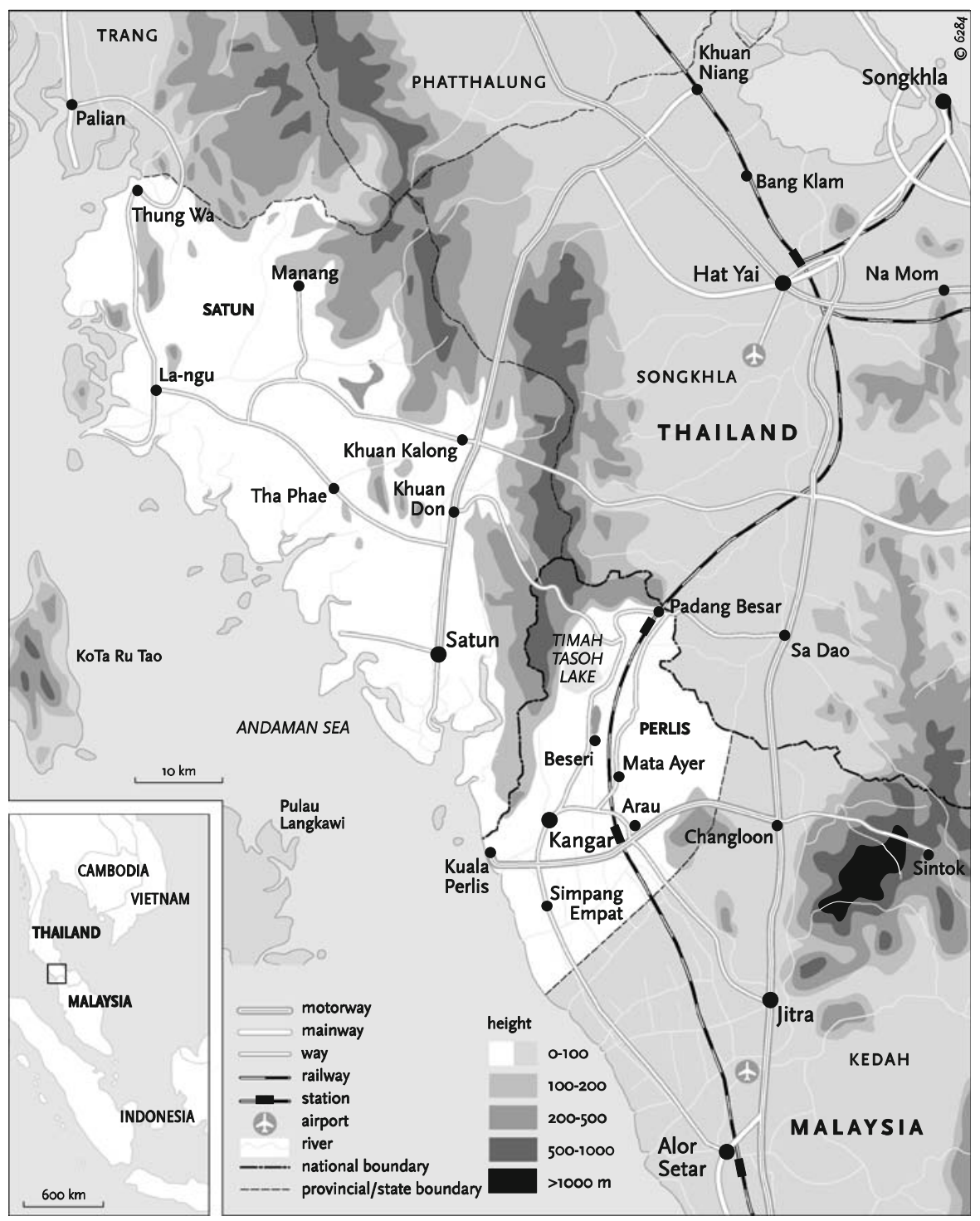

Figure 1 Map of Satun and Perlis. Map produced by Geomedia, UU based on various sources

Although both Malaysia and Thailand belong to the middle-income category, patterns of economic growth and institutional frameworks are by no means the same. Table 1 shows that Malaysia is clearly the more advanced country: its GNI and HDI per capita are substantially higher and have increased faster; agriculture is no longer the major sector of employment and its economy appears more open; or at least, it has a highly open export manufacturing sector. Reflecting these differences in national contexts, the two study areas display different economic profiles. Whereas Satun remains essentially rural, with more than half of its income and employment based on 
agriculture and fisheries, Perlis boasts a rather diversified economy with services as the lead sector along with some manufacturing, including foreign plants (Table 2). Remarkably, construction emerges as a key component of the Perlis economy, suggesting considerable dynamism. In contrast, Satun's non-primary economic activities are limited to a small services sector based in its capital Satun Town, as well as some processing of primary products, notably a large tuna canning plant.

Table 3 compares the institutional and political aspects of the Thai and Malaysian national economies, based on an extensive list of sources. Similar to the variety in economic performance, many differences in national institutions can be observed. A major difference is the role of the private and public sector. In Thai capitalism, firms occupy a more strategic position, whereas governmental authorities are very active in Malaysia. This is confirmed by the government expenditure indicator in Table 1. Another striking difference is the relation between ethnicity and economic institutions. Since 1971 the Malaysian government has actively sought to enhance the economic position of the Malay (Bumiputera) majority relative to the ethnic Chinese and ethnic Indian minorities, most notably through the so-called new economic policy (NEP). Ethnic Chinese businesspeople also account for much of the economy of Thailand, but this has not resulted in similar ethnic-based policies. Overall, in Schmidt's (2003) terminology Thailand has a managed variety of capitalism, with some features of a market variety, whereas Malaysia is closer to a state variety of capitalism. How these varieties impinge upon our empirical cases will be analysed in the following.

To accommodate the theoretical considerations discussed in the previous section, we adhered to the following set-up. With respect to private sector development we analysed inter-firm relations, corporate governance (specifically access to finance), and human capital formation; the last-mentioned as a proxy for Hall and Soskice's institutions pertaining to industrial relations. Given the expected role of personal capitalism (especially significant in the case of Thailand) and robust state intervention in Malaysia (Table 3), political power and personal capitalism are included in the analysis, as already discussed.

Table 1 Socio-economic differences between Thailand and Malaysia.

\begin{tabular}{lcccc}
\hline & Malaysia & \multicolumn{3}{c}{ Thailand } \\
\hline & 1975 & 2004 & 1975 & 2004 \\
Total population (millions) & 12.3 & 24.9 & 41.3 & 63.7 \\
HDI index & 0.616 & 0.805 & 0.615 & 0.784 \\
GDP per capita rank (ppp)-HDI Rank & & -4 & & -9 \\
Labour force (\%) & 1990 & 2005 & 1990 & 2005 \\
Agriculture & 26 & 15 & 64 & 43 \\
Industry & 20 & 20 & 10 & 15 \\
Services & 54 & 65 & 26 & 42 \\
Government expenditure (\% of GDP) & 13.8 & 13.1 & 9.4 & 11.8 \\
& 2000 & 2004 & 2000 & 2004 \\
GNI per capita (atlas method, US\$) & 3,390 & 4,520 & 2,010 & 2,490 \\
Total trade (\% of GDP) & 199.5 & 195.7 & 107 & 129.4 \\
Total external debt (\% of GNI) & 50.6 & 46.6 & 66 & 32.4 \\
\hline
\end{tabular}

Sources: UNDP, 2006; ADB, 2006. 
Table 2 Basic indicators of Satun and Perlis.

\begin{tabular}{lrrrr}
\hline & \multicolumn{2}{c}{ Satun } & Perlis \\
\hline & 1990 & 2004 & 1990 & 2004 \\
Total population & 227,000 & 270,000 & 188,000 & 218,000 \\
Islam (\%) & 67 & 68 & 79 & 84 \\
Labour force (\%) & & & 33 & 15 \\
Agriculture & 74 & 57 & 22 & 24 \\
Industry & 13 & 10 & 21 & 34 \\
Private services & 10 & 26 & 24 & 27 \\
Public services & 4 & 7 & & 2,589 \\
Per capita GRP in US\$ & & 1,630 & & 564.4 \\
GRP in US\$ (million) & & 439.8 & & \\
\hline
\end{tabular}

Sources: Auditor General, (2006), Department of Statistics (1993/2005).

The next two sections will elaborate on ownership and control, inter-firm relations, access to finance, human capital formation and the political dimension of institutions within two industries: the seafood industry in Satun and the construction/ real estate industry in Perlis. It may seem odd to select two fairly different industries for a comparative analysis. Differences in organisation and characteristics of the two industries do indeed impose limitations on comparison. The reason why they have nevertheless been selected is that both industries clearly reveal the way national institutional complementarities affect patterns of regional development. Thus, seafood in Satun and construction in Perlis constitute the emblematic industries of their respective regions, which reveal key features of the two models under scrutiny.

Data collection and subsequent analysis of the two regional economies were not limited to these two industries. The data base covers overall economic activity in Satun and Perlis. Data are drawn from two main sources. First, a firm survey conducted between July 2004 and December 2004 was concerned with mapping institutional relations, including ownership and control features, networking patterns

Table 3 Thailand's managed variety and Malaysia's state variety of capitalism.

\begin{tabular}{|c|c|c|}
\hline & Thailand & Malaysia \\
\hline Political economy & $\begin{array}{l}\text { Agriculture also successful in } \\
\text { international markets; government } \\
\text { is enabler, facilitator }\end{array}$ & $\begin{array}{l}\text { Clear dual political economy: } \\
\text { globalized enclaves with domestic } \\
\text { protected markets; government is } \\
\text { interventionist, dirigiste }\end{array}$ \\
\hline Domestic coalitions & $\begin{array}{l}\text { Sino-Thai entrepreneurs active } \\
\text { in both domestic and international } \\
\text { economy; entrepreneurs often active } \\
\text { in politics }\end{array}$ & $\begin{array}{l}\text { Nurturing of Bumiputera business } \\
\text { elite, closely related to UMNO } \\
\text { joint ventures between ethnic- } \\
\text { Chinese and Malay firms }\end{array}$ \\
\hline Side payments & Relatively moderate & Huge and many different kinds \\
\hline Inter-firm relations & $\begin{array}{l}\text { Competitive plus...cooperative, } \\
\text { mutually reinforcing and networked based }\end{array}$ & State led state mediated \\
\hline Access to finance & Major role for banks & Major role for state \\
\hline
\end{tabular}

Sources: Case, 2005; Gomez, 2002; Hewison, 2005; Jomo, 2003, Krongkaew, 1999; Mackie, 2003; Pasuk and Baker, 2004; Schmidt, 2003; Wingfield, 2002. 
of firms (supplies, customers, competitors, civil servants), the nature and frequency of these relations (contracts, meetings, role of business associations) as well as access to finance (role of banks, government loans, shareholders and other intra-firm sources). A total of 44 firms were approached in Satun (of which 6 refused to cooperate), and 48 in Perlis (of which 9 refused). The businesses included in the study represent all large and a sample of medium-sized companies. In Satun, firms from the latter group, defined as having a registered capital between Thai Baht 1 million and 15 million, were randomly sampled from a comprehensive digital list of the Department of Commerce. Since there is no single reliable register of all firms in Perlis, sampling there had to be carried out from a list derived from several sources. In order to assure coverage of Bumiputera as well as ethnic Chinese firms, lists from both the Malay and Chinese Chambers of Commerce were used. In addition, the listings of Malaysia's Company Commission (SSM) and the State Economic Development Corporation were obtained to complement our sampling frame. In Perlis medium-sized companies were defined as employing between 5 and 300 workers. ${ }^{4}$ Answers were then processed by the SPSS software package for simple statistical analyses. Very small firms were excluded from the research.

Second, between February 2006 and June 2006 semi-structured and open interviews were conducted with a variety of organisations and individuals: representatives from associations, national and regional governments, bank managers and journalists. In Satun, 29 key informants were interviewed, and 33 in Perlis. ${ }^{5}$ In both Satun and Perlis firms were approached in person. In virtually all surveys and interviews in Satun interpreters were used. In Perlis $50 \%$ of the surveys and interviews were carried out without the aid of an interpreter, as managers and owners of larger firms were generally able to communicate in English. Some $25 \%$ of the data gathering took place with a Bumiputera interpreter and the remaining 25\% with an ethnic Chinese interpreter (mostly Hokkien). Interviews took around one hour on average and predominantly served to cross-check findings from the survey, and gauge backgrounds, motives and interests. The interviews also dealt with aspects of human capital formation (training of workers and education policies) and the political dimension of institutions (networks involving politicians and entrepreneurs, commercial interests of politicians, the conduct of tender processes). Of course, the use of interpreters may lead to slight distortions of the information gathered. Interviewees were usually very cooperative, but several respondents in Perlis showed some reluctance to disclose information that was deemed sensitive. The interviews were analysed through identifying keywords, allocation answers to the keywords and then comparing the answers. For a full outline of the research methodology, see Andriesse (2008).

\footnotetext{
${ }^{4}$ Due to differences in registration of firms, size classification methodology had to vary somewhat between the two countries.

${ }^{5}$ Some of these interviews were conducted outside the research areas: Hat Yai and Bangkok for the Satun case and Alor Setar and Putrajaya for the Perlis case. In recent years, many governmental authorities have transferred their offices from Kuala Lumpur to Putrajaya.
} 


\section{Institutional arrangements in the Satun seafood industry}

\section{The seafood industry}

Thailand is a well-known exporter of seafood, harvested from fisheries as well as aquaculture. In 2004 Thailand ranked 3rd worldwide in terms of export value, and 5th in terms of volume; an improvement from 8th and 11th positions respectively in 1984 (FAO, 2007). Perhaps even more remarkable was the emergence of a Thai multinational, the Charoen Phokpand Group, as a leading actor in organising the global value chain for shrimps (Goss, Burch, \& Rickson, 2000; Pananond \& Zeithaml, 1998). The largest concentration of fishery activities is still based in the Bangkok area. However, unsustainable practices especially in shrimp aquaculture have prompted the industry to gradually spread south along the Gulf of Thailand, and further on the Andaman Coast, in the classical pattern of a moving resource frontier.

As the southernmost province flanked by the Andaman Sea, bordering Malaysia, Satun was one of the last parts of Thailand to be included in this commercial fishery. Although it is a small and remote province, with a population of approximately 270,000 , it is not a particularly poor one. It ranked 20th out of 76 Thai provinces on the UNDP Human Achievement Index in the 2007 issue (UNDP, 2007). Thailand's space economy shows a concentration of manufacturing and modern service industries in the Bangkok area, while the provinces serve mostly as suppliers of raw materials. Satun can be seen as a resource frontier in this constellation. Latex extraction from rubber trees and ocean fishing are by far its most important industries. The former is mainly carried out by smallholders and a single latex processing firm (most of the processing takes place in neighbouring Songkhla Province). The fisheries industry in Satun has seen the rise of a seafood cluster (a group of spatially concentrated and closely linked firms), consisting of boat owners, fishermen, fish processing establishments, transportation firms, ice factories and support activities. Satun has two fishing ports: Tammalang, just south of Satun Town, and Pak Bara near La-ngu. Satun's two ports are responsible for $25 \%$ of all fish handled along Thailand's Andaman coast (Department of Fisheries, 2005). The prominence of fisheries in Satun is reflected in the composition of its gross regional product (GRP) and the labour force. The share of fisheries in Satun's GRP excluding processing and related activities was $20 \%$ in 2005, and approximately $20 \%$ of the total labour force work in the fisheries cluster (NESDB, 2007; NSO, 2005). ${ }^{6}$ Interestingly, the fisheries industry on the Malaysian side of the border is substantially smaller than in Satun, in spite of similar resource conditions.

Why has this seafood cluster emerged in Satun? It is clearly a private-sectordriven industry that in its rise reflects Satun's resource base as well as the role of nearby Hat Yai as the economic centre for the south of Thailand. Seen from Hat Yai, Satun is an attractive new location for the seafood industry, tapping into relatively little used resources when fisheries on the Gulf of Thailand coast had already been well established (e.g., Pattani). Businesspeople from Hat Yai and their relatives

\footnotetext{
${ }^{6}$ The latter percentage is based on estimation: summing up the number of fishermen and the number of employees working in firms of the seafood cluster.
} 
played a considerable part in the creation of the Satun seafood cluster. Moreover, Satun's Muslim Malay population is prepared to do the hard work required of fishermen at sea, an occupation less popular among Thai populations further north.

\section{Institutional arrangements}

What institutional arrangements drive the Satun seafood cluster and do institutional complementarities affect its performance? In terms of ownership and control, it is striking that all surveyed firms within the cluster are owned by Sino-Thai businesspeople - this in contrast to the Muslim majority in Satun's population. In several cases, one of the parents of the owner migrated from China, but most have lived in Thailand for generations. Typically, firms in the seafood cluster are independent, not subsidiaries of other firms. Some have the legal form of limited partnerships (at least two shareholders), others are limited companies (a minimum of seven shareholders). As a rule, all shareholders are relatives. A considerable number of these shareholding kin live in Hat Yai, the regional business hub. Management tasks are generally carried out by the owners themselves, as employees are not considered important stakeholders. In this respect Satun fits the general Chinese family-based business pattern of personal capitalism: i.e., the coupling of ownership and control and an orientation towards shareholders and kin rather than (other) stakeholders. The employees, mostly Muslim Malays and migrants from Myanmar, are recruited for their willingness to work hard for low wages; personal ties do not play a significant role and long-term commitments between employer and employee are not actively pursued.

The most prominent firm in the cluster and by far the largest firm in the province is Siam Tin Foods. It was established in 1986 by a Bangkok entrepreneur, introduced to Southern Thailand through his wife. He considered Satun a good location for seafood processing because of its abundance of seafood, labour and cheap land. Since then, the firm has grown to employ 1,300 workers, exporting canned fish to Europe and the United States. The firm has 10 shareholders in addition to the founder-cum-managing director who holds $25 \%$ of the stock. Similar to Siam Tin Foods, other entrepreneurs have moved in to take advantage of Satun's comparative advantages. The second largest firm (100 employees) is a shrimp processing company owned by the mayor of Satun Town. His most important client is the Charoen Phokpand Group that orchestrates the extensive logistics necessary to get Thai shrimps on dining tables all over the world.

The firm survey reveals highly informal, personal and networked inter-firm relations. Firms at the start of the value chain have suppliers outside Satun (chemicals for an ice factory, equipment for boat owners) and clients in Satun (processing and distribution firms), whereas processing firms often have local suppliers, but deliver to clients outside of the province (wholesalers and exporters). Suppliers and clients within the cluster rarely sign formal contracts, but deal with each other on an informal and personal basis. The owner of an ice factory commented: "I like to give suppliers and clients a present for Chinese New Year and thank them for their support." The cooperation between this firm and a distributor is illustrative of the informal nature of inter-firm relations: "When we want some material from Bangkok ..., we ask them to transport material from suppliers [sic]; Our clients agree, because they normally drive their trucks back to Satun empty." 
Cooperation among entrepreneurs is also facilitated through three local organisations: the Satun Chamber of Commerce, the Sino-Thai Chong Hua Association and the local Rotary Club. Moreover, kinship relations frequently facilitate business contacts. Hongyen Tammalang, for instance, a fish processing firm that also owns boats, has as its most important client a relative in Chumphon Province. Overall, inter-firm relations fit into the so-called guanxi style of doing business (Li, 2007). Guanxi can be considered as a set of specific informal institutions, which enable entrepreneurship and in which personal connections are often key drivers. In fact, most entrepreneurs in Satun's private sector are Sino-Thai who practise guanxi (Andriesse, 2006). Although inter-firm relations in Thailand are also driven by competition (Table 3), guanxi-style cooperation stands out in Satun, perhaps fostered by the lack of interaction between the local business elite and the Muslim majority.

However central the family-based Sino-Thai private company may be to Satun's economy, it is complemented by relatively easy access to finance. According to Carney and Gedajlovic (2001), personal capitalism "has negative implications regarding a firm's ability to raise financial capital." This is the case in Malaysia, as will be clarified in the next section, but in Thailand banking has greatly contributed to private sector development (Mackie, 2003; Wingfield, 2002). Hewison (2001) and Suehiro (1989: 110-172) have traced the rise of these Thai banks to successful SinoThai families able to build large financial conglomerates (some as spin-offs from rice milling) with the support of the Thai bureaucracy and military leaders in the 1950s. Even in a peripheral province such as Satun many banks have opened a branch there. On average $58 \%$ of their transactions are related to personal banking, and $42 \%$ to corporate banking. ${ }^{7}$ Indeed, a majority of the seafood firms mentioned banks as the main source of start-up capital. Financial risks are reduced by also relying on shareholders (read relatives). Furthermore, finance is sourced via networking in the associations as presented earlier.

On the one hand the complementarity of guanxi institutions and relatively easy access to finance appears to benefit the growth of the seafood cluster, but on the other hand employees are to some extent excluded from participation. Sino-Thai entrepreneurs seem less committed to foster relations with workers by paying them good wages (in fact workers from Myanmar often receive less than the minimum wage of US $\$ 88$ per month (BOI, 2007)), or by providing social security or training to workers. As a consequence, employees lack incentives to invest in their jobs and human capital formation is limited. Moreover, few banks offer financial products conforming to Islamic laws, which may well constrain private business development among Muslims. As for the public sector, the Department of Fisheries and the Fish Marketing Organisation offer some support and regulation services (safety and quality inspection, information supply, etc.), but are not directly involved in the development of the cluster, nor do they provide credit for private sector development. On the whole, the public sector is not much concerned with the interests of Islamic workers and labour migrants from Myanmar. Thus the relative neglect by the public sector contributes to the continuing economic exclusion of the majority population in the province.

\footnotetext{
${ }^{7}$ Based on interviews with bank managers.
} 
Finally, the political dimension of the institutional arrangements remains to be discussed. Personal power networks in the seafood cluster evolve in two ways. Firstly, leading entrepreneurs may be consulted for policy advice. The managing director of Siam Tin Foods, for instance, acts as an economic adviser to the Governor of the province. This enables him to obtain information and to coordinate matters relevant for his businesses. Secondly, the guanxi style of doing business has a political dimension as many leading Sino-Thai entrepreneurs are active in the Satun Town Municipal Government. As already noted, the mayor owns a shrimp farm, and a vice mayor and another member of the Satun Municipal Council (a younger brother to the former mayor) own many fishing boats. Municipal politics is another platform for the seafood entrepreneurs to coordinate business with each other. Sino-Thai businesspeople are elected into municipal office as Muslims are not a majority in Satun Town. Ethnic-based voting explains why they cannot become national politicians. Members of Parliament representing Satun Province are always Muslims, reflecting the population composition. Therefore, there are no effective entrepreneur-politician networks linking the province's business interests with provincial and national politics, as is the case in many other Thai provinces (Askew, 2006; Nelson, 2005; Pasuk \& Baker, 2004; McVey, 2000). The Satun Town Council has emerged as a substitute locus of political representation for Sino-Thai entrepreneurs, but it is unable to secure their interests. The Town Council does not offer them access to decision making and budget allocations at the national level, which is far more important than what can be done locally.

\section{Institutional arrangements in the Perlis construction and real estate industry}

The construction and real estate industry

The second empirical case is the construction and real estate industry in Perlis, the Malaysian state bordering Satun. In contrast to Satun's seafood cluster the construction and real estate industry is a purely domestic activity, not involving exports. However, it can actually be seen as the key driver in the regional (state) economy. Construction and real estate have long been important in Malaysia's economy, particularly so in the beginning of the 1990s when then Prime Minister Mahathir, flush with success in export manufacturing and with revenues from oil and gas exports, initiated several "mega projects." In the more sober period that followed, some projects were scrapped. However, the Ninth Malaysia Plan (2006-2010) has revived the construction industry as a key instrument of economic policy. This is specifically notable in the small and relatively peripheral state of Perlis with a population of 210,000 of whom $84 \%$ are Bumiputeras and $10 \%$ ethnic Chinese. It is thus part of the Malay heartland of Malaysia: a state predominately populated by the politically powerful but economically less favoured Bumiputera population. As such, Perlis ranks among the less developed states. Nevertheless, Perlis is considerably better off than its Thai neighbours, as reflected in its per capita GRP, 59\% higher than Satun's, and in a range of other indicators such as per capita number of hospital beds, teachers, private cars, and so on. 
In stark contrast to Satun and perhaps surprising for a relatively rural and peripheral part of the country, the public sector is the main driver of the regional economy. Public services in themselves are a backbone of the Perlis economy, engaging $27 \%$ of the total labour force. The importance of the construction and real estate industry is directly linked to the key role of the public sector. In 2004 construction alone contributed $5.9 \%$ to GRP and employed no less than $10 \%$ of the total labour force - much more than corresponding figures for Satun at 2.2\% and $4.4 \%$ respectively (unfortunately, data for real estate activities are not available). The prominence of the construction/real estate industry in Perlis is based on several large public projects, among which include schools, tourist facilities, highways and new offices for the Perlis State Government. Recently, Perlis has embarked on a strategy to become a "knowledge state." Several new schools and colleges were welcomed to the state, the Northern Malaysia University College of Engineering (KUKUM) being the most important. As the Perlis Sate Government has few financial resources, the Federal Government funds virtually all projects. ${ }^{8}$ Private construction initiatives are relatively unimportant.

The role of construction and real estate is not immediately obvious from the statistics quoted. The point is that in Perlis, the state (federal and local) actively intervenes in economic life in efforts to create new regional competitive advantages in order to promote the position of the economically disadvantaged but politically powerful Malay population. This is in contrast to Satun, where private entrepreneurs take the initiative to exploit the existing comparative advantages in natural resourcebased activities. Indeed, here we touch on the key feature of the regional economy, namely that it is essentially based on Malaysia's extensive system of side payments to the economically less favoured Malay heartland. The level of income, welfare and services enjoyed by the Perlis population has relatively little to do with its basic industries and the market sector. In reality, the dynamism of the Perlis economy is generated by transfers from the Federal Government, funds channelled into a seemingly never-ending series of project ideas to promote this predominantly Malay state. Whether it concerns a halal food hub, tourism facilities, industrial estates or promoting a knowledge-based economy; each project translates into construction activities for local firms that usually consist of a Malay front operation, often with political-administrative connections, and ethnic Chinese junior partners and subcontractors. Although many development projects are undoubtedly serious in intent, many others can be challenged in terms of their economic viability. At times, "having projects"-i.e., spending transfers on local construction-seems more important than the eventual use of completed facilities. This raises the impression of a regional economy focused more on federal transfers and the corresponding opportunities for rent seeking - especially in construction and real estate - than on local productive performance.

\footnotetext{
${ }^{8}$ To put things in perspective: the total costs of the new KUKUM are around RM 800 million, the highway between Kuala Perlis and Changloon RM 400 million, but the total annual revenues of the Perlis State Government are less than RM 100 million.
} 
In contrast to Satun, in Perlis ownership and control of firms is not usually in one hand. The construction and real estate industries comprise three types of firms. The first consists of state-owned firms. The public Perlis State Economic Development Corporation (SEDC) owns a property developer, Perlis Holdings, and a contracting firm. Each Malaysian state has such a corporation in order to promote economic development, especially for Bumiputeras, by investment in promising activities. Furthermore, another contractor is directly controlled by the office of the Perlis Menteri Besar (MB, Chief Minister of the State Government). The CIMA cement plant with 300 employees is predominantly owned by the UEM Group, which in turn is part of the investment portfolio of Khazanah Nasional, the federal holding company. Secondly, there are several Bumiputera-owned contracting firms. Thirdly, some contractors, stone quarries and property developers are owned by ethnic Chinese entrepreneurs. The larger firms among these frequently include one or more Bumiputeras among their shareholders, so as to improve their chances for obtaining public sector orders and licenses. This form of inter-ethnic cooperation has been labelled Ali-Baba joint ventures (Bardhan, 2005: 195; White, 2004). Personal capitalism is much less prevalent in the state. According to several interviewees the overarching goal of the state-owned firms is to provide employment and create multiplier effects for the regional economy rather than to increase shareholder welfare (i.e., of the Perlis State or Federal Governments). A revealing example is the SEDC, currently the second largest employer in Perlis but burdened by an unfavourable financial position. According to the Malaysian Auditor-General (2006), its assets exceeded liabilities by a factor of merely 1.2 between 2002 and 2004. This shows an orientation in favour of other stakeholders than owners and managers, not unlike Schmidt's (2003) account of France's state capitalism between 1950 and 1980. Moreover, ownership and control are separate in the sense that high-ranking civil servants and politicians are able to fire the managers of the state-owned firms.

The firm survey revealed that inter-firm relations are highly state-led and statemediated. We cite two examples as illustration: The SEDC has recently commenced on the extensive Padang Besar Development project involving the construction of an industrial zone, a transhipment centre, tourist facilities and residential areas. Another state-owned company, Perlis Holdings, has been selected as the property developer for the first phase of the project. The second example is a new strategy in the Ninth Malaysia Plan, of transforming Perlis into a Halal Hub (EPU, 2006); another attempt to create a comparative advantage by state intervention. The RM 10 million project should make Perlis a processing and marketing centre of foods, pharmaceuticals and beauty products that comply with Islamic prescriptions.

It is no surprise that private actors in the construction and real estate industries primarily look at the public sector. Their aim is to win as many orders as possible. At the same time, however, the public sector wishes to award orders to state-owned firms, constraining the circulation of money and opportunities beyond the public sector. In this regard it competes directly with the private sector. The overall results of this public sector role are that public agencies stand at the centre of the regional economy, that supply relations are relatively formal, contractual and impersonal, that the role of business associations (even the construction association) remains limited, and that 
virtually no cooperation and coordination take place among competitors. Instead, firms cultivate close relationships with government and associated agents such as the SEDC, the Public Works Department, as well as civil servants and politicians of the Perlis state government - if possible the MB himself. These institutional arrangements were also found to be typical of other industries apart from construction and real estate. By a wide margin, public authorities are mentioned as the most important clients of firms interviewed (Andriesse, 2008). Ethnic Chinese construction firms have a special position, since the public sector generally prefers to award tenders to Bumiputera firms. Practising guanxi within the industry does not generate work, so entrepreneurs try to team up with Bumiputera businesses, either in Ali-Baba joint ventures or as their subcontractors. Thus, the traditional separation walls between ethnic groups are indeed to some extent breached as a result of state-led and state-mediated inter-firm relations, though not quite in the way intended. Our empirical findings from Perlis with respect to the role of ethnicity match the observations for Malaysia in general made by Gomez et al. (2003).

In addition to inter-firm relations, the government also plays an active role in shaping access to finance, albeit with limited success. They obviously support the state-owned firms financially, and operate a large number of financial programmes for Bumiputera entrepreneurs that have not been very effective. The majority of Perlis's Bumiputera contracting firms still rely on their owners for start-up capital. Interviews with bank managers generated similar results: only $18 \%$ of their transactions concerned corporate banking (as opposed to $42 \%$ in Satun). Most problematic is the situation for small ethnic-Chinese contractors. They can not rely on extensive guanxi networks and simultaneously they face difficulties in obtaining capital from banks as they often lack collateral. This confirms the observation that personal capitalism can impose limitations on raising capital (Carney \& Gedajlovic, 2001). In fact, small ethnic Chinese contractors denied close relationships with Bumiputera firms and the public sector operate in relative isolation, heavily constrained by the Malaysian state variety of capitalism. These findings reveal that personal capitalism, particularly the way of doing business among ethnic Chinese entrepreneurs, can vary substantially in response to differences in national contexts.

In terms of distributive equity, a major advantage of the dominant public sector role is the inclusion of employees into the development process. As an important employer, this sector provides much more social security than enjoyed by the vulnerable employees of Satun's seafood cluster. In addition, the many technical colleges established recently as a result of the knowledge strategy contribute to human capital formation in Malaysia, even if the importance of this contribution cannot be assessed as yet. College graduates generally do not find jobs in Perlis, but in other more prosperous states of Malaysia. Human capital formation in the construction industry is much less important. The subcontractors, who are responsible for a large share of the actual construction work, try to cut costs as much as possible and often hire labourers on a temporary basis.

A good indication that the political dimension of institutional arrangements should not be overlooked is found in the business strategies of large ethnic Chinese contractors and property developers. They have found their way to lucrative business via Ali-Baba joint ventures and the cultivation of close personal relationships with the Bumiputera elite. One ethnic Chinese property developer, for example, is close to the former Menteri Besar (MB) of Perlis, while his brother has managed to befriend 
the Raja (King) of Perlis. This mixing of personal links with business interests is also common practice among Bumiputera firms. Several interviewees claimed that open tendering for construction projects is hampered by the MB himself who allegedly preferred to allocate projects to four associates. Influential "crony" contractors have thus won many bids, including one for the new Perlis Court of Justice. Similar outcomes in another regional context in Malaysia have been convincingly documented in Shamsul (1986). ${ }^{9}$ In an effort to increase opportunities for smaller contractors Prime Minister Abdullah Badawi has ordered the Public Works Department to subdivide large projects among several contractors. This has had an effect in Perlis. The tender process for the Padang Besar-Changloon highway was cut into three parts. Three different contractors are building the highway: one hails from outside Perlis and two are local Ali-Baba joint ventures, one of which is associated with the MB. The five issues discussed lead to the following institutional complementarities within the Perlis construction and real estate sector: on the one hand, a leading role of the public sector in terms of ownership and inter-firm relations is accompanied by a low level of interaction, cooperation and coordination among private contractors and developers who focus their attention on gaining access to projects financed by the Federal Government. Moreover, a relatively good performance in terms of regional economic growth and other distributive effects is combined with doubts about economic efficiency.

\section{Discussion and conclusions}

Our findings in Perlis and Satun clearly show the distinctive capitalist settings of the two countries involved. This is no surprise, but our study also reveals that institutional complementarities in Malaysia and Thailand have produced rather different outcomes in terms of regional development in the relatively peripheral regions straddling the international border. Table 4 summarises the main empirical findings. Thailand's variety of capitalism has forged a private-sector-dominated type of regional economic development in Satun, based on the exploitation of its comparative advantages by local entrepreneurs organised in national (and international) value chains. This produces a relatively robust and competitive local private sector. At the same time, guanxi institutions linking the dominant Sino-Thai business community tend to exclude the Muslim majority of the population. Muslims are virtually absent from private sector development in the province, while employment in the private sector also offers limited perspectives due to the nature of personal capitalism. Human capital formation outside the realm of family firms appears limited. This is not much corrected by a public sector that largely refrains from intervening in regional development, beyond the delivery of infrastructure and supporting services. This aloofness, together with the gap between the Sino-Thai business community and the Muslim majority, may shed some light on the causes of

\footnotetext{
${ }^{9}$ Unfortunately, more recent sources are not available. The reason is probably that Malaysian authorities try to reduce the number of politically sensitive studies. The fact that Shamsul's publication enjoyed a reprint in 2004 is telling for the limited number of other newer studies. In contrast, numerous political studies have been published concerning Thailand, the Philippines and increasingly, Indonesia.
} 
Table 4 Summary of empirical results.

\begin{tabular}{lll}
\hline & Seafood industry in Satun & Construction industry in Perlis \\
\hline $\begin{array}{l}\text { Ownership and control } \\
\text { Inter-firm relations }\end{array}$ & Coupled & Separated \\
Access to finance & Informal networking, guanxi dynamics & Formal, contractual, state-led \\
& Easy, banks and kinship ties & $\begin{array}{l}\text { Relatively difficult, owners/ } \\
\text { shareholders }\end{array}$ \\
$\begin{array}{l}\text { Human capital formation } \\
\text { Political dimension }\end{array}$ & Limited & Considerable \\
& Limited to Satun Municipality, & Bumiputera policies, support \\
& few links with "Bangkok" & from Federal Government \\
\hline
\end{tabular}

conflict in neighbouring provinces in Southern Thailand, even if conditions there are not quite the same as those observed in Satun.

In contrast, the economic make-up of Perlis can only be understood by considering Malaysia's state-led economic framework - or specifically, the way in which it is manifest in a peripheral Malay (not just Malaysian!) region. One objective behind massive investment in public (or public-private) projects is to forge new competitive advantages in line with ambitions of turning the economically disadvantaged Malay majority into an enterprising part of society. This policy has yielded some successes in regional development. It has transformed Perlis from a rural into a more diverse, servicebased economy, with higher levels of employment, income and services. However, it remains unclear whether the Malaysian model will ultimately succeed in transforming its peripheries. It was evident in our discussion that state-led development has given rise to considerable rent seeking, while doubts may be raised about the long-term economic sustainability of much public sector investment. Human capital formation may occur, but its impact on the local economy is unclear. Also, some crowding out of private sector initiatives and a lesser degree of social capital formation could be observed, which is likely to jeopardise regional development in the longer run.

What, then, are the more general implications of our findings in Satun and Perlis? To what extent does our analysis allow conclusions about the role of institutional frameworks in regional development, especially in non-core regions in Pacific Asia? In the first place it has been shown that institutional complementarities do play an important role in setting regions on a particular development trajectory. Our cases demonstrate that effectively complementing institutions have a much more powerful impact than arrangements that evolve in isolation. Thus, development policies should aim at promoting positive complementarities in regional economic frameworks. In this respect Hall and Soskice (2001: 45-51) argue that economic policies are effective "if they are incentive compatible," i.e., in line with the coordinating capabilities embedded in the existing institutional environment. This may sound obvious, but is not always understood when policy makers import "best practice" models from other settings, without considering the match with the local context.

A good example of how differences in institutional environments may affect economic behaviour is observed in the operation of the Chinese business communities in the two study regions. The comparison of Perlis and Satun suggests that entrepreneurial practices among ethnic Chinese are not as homogeneous across Southeast Asia as put forward by Bjerke (2000), Perry (2003), Yeung (1999) and Weidenbaum and Hughes (1996: 23-61). In our study, networking by Chinese 
entrepreneurs is conditioned by a rational response to differences in the national institutional context, namely one that compels them to team up with Bumiputera partners in Malaysia, and one that fosters guanxi-style cooperation within the community in Thailand.

Beyond institutional complementarities, our findings raise two additional issues not adequately covered in much of the literature on capitalist varieties. One is the distributive dimension of economic systems, and the other issue is that of their sustainability in the longer term.

Each national variety of capitalism not only defines conditions for economic activity, but also determines how benefits are to be divided among different stakeholders. As mentioned, Jayasuriya (2004) conceptualises Asian economies as consisting of a "mercantilist" growth coalition around the export sector, combined with a transfer mechanism ("side payments") for the benefit of key interest groups outside of the leading economic sector. The first component (growth coalition) obviously concentrates on creating optimal conditions for economic performance while side payments take care of the distribution of wealth. Although the importance of distribution issues is fairly widely accepted, much of the literature on capitalist varieties favours the first question - maximise growth - above the distribution issue. Nevertheless, the comparison of regions in Malaysia and Thailand highlights the key role of distribution mechanisms in the definition of their respective national economic systems. Malaysia emerges as a state-led economic system not because of considerations of economic strategy, but due to the political necessity of accommodating the aspirations of the Malay majority of its population. Although Malaysian policies often profess to aim at boosting the role of ethnic Malays in the national economy, they are rather more successful in redressing wealth distribution than in changing performance. Thus, a relatively peripheral state such as Perlis benefits from transfer payments by virtue of the ethnic composition of its population (mostly Malays), and not so much as compensation for its peripheral position in the national space economy. Policies are also more effective in improving income and consumption levels than in creating competitive advantages in Perlis, as we have seen. In Thailand, side payments are less conspicuous although they have been used to cater to the constituents of coalition governments in the past, and in order to mobilise the provincial support base of the Thaksin governments. In comparison to Malaysia, Thailand looks relatively disinterested in redressing economic imbalances between social groups and regions; in this respect it matches Tipton's (2007) characterisation of Southeast Asian states as relatively weak in social engineering. But then, Thailand's political constellation is less affected by such wealth gaps. Southern Muslims may see little of the benefits of growth, but their disaffection is seen as a local matter rather than as a threat to national stability - and, thus, does not trigger a response in the design of economic institutions. This perpetuates the problem. Creating and maintaining balances - between social and ethnic groups, and between the constituent regions of a country is vital for successful economic and social models, from an efficiency as well as an ethical point of view. In fact, both the Malaysian and Thai cases show few signs of overcoming imbalances. This brings us to the last issue, that of institutional sustainability.

Institutional complementarities may enhance economic performance and policy effectiveness; they may also have the effect of locking regional development into a 
trajectory that is unsustainable in the longer term. Both of our cases show some disturbing features in this respect. The Malaysian case depends on transfers from the national economy that can be sustained in a context of relatively high economic growth and the ability of the government to use oil and gas revenues for side payments, rather than having to rely on them for its own operations. Such conditions are not likely to last in the long run. Thus, the challenge is for such regions to develop local income sources before the flow of funds from Putrajaya runs out. As we have seen, however, the economic rationale for much of this investment is in doubt. The emergence of new competitive strengths cannot be taken for granted. The Malaysian system induces stakeholders to try to gain access to the transfer flows, not to optimise their impact. In the Thai case, unsustainable environmental pressure may well undermine the current economic model. Unfettered private development of fisheries, aquaculture, and tourism may well exhaust the natural resource base before diversification into other industries has sufficiently progressed. Thailand's record in taking timely remedial action is hardly encouraging: witness, for instance, the abandoned aquaculture ponds on the Gulf of Thailand coast, poisoned by speculative short-term exploitation. Moreover, the socio-economic cleavages observed raise worries about the social sustainability of the development trajectory. The ethnic conflict in the neighbouring provinces of Southern Thailand is a crude reminder of this problem. The disturbing point in both cases is not the lack of balance per se: each economic system probably will prove unsustainable when current trends are projected into the future. The problem is a lack of corrective mechanisms or countervailing forces - precisely because of institutional complementarities. Thus, in our view, the sustainability of economic systems, or their ability to adapt, deserves more attention in the study of capitalist varieties. In doing this, the way in which distributive questions are accommodated or ignored is likely to be a major factor.

Open Access This article is distributed under the terms of the Creative Commons Attribution Noncommercial License which permits any noncommercial use, distribution, and reproduction in any medium, provided the original author(s) and source are credited.

\section{References}

ADB 2006. Key Indicators 2006: Measuring policy effectiveness in health and education. Manila: Asian Development Bank.

Allen, M. 2004. The varieties of capitalism paradigm: Not enough variety? Socio-Economic Review, 2: 87-108. Andriesse, E. 2006. Regional varieties of capitalism: Inter-firm relations and access to finance in Satun (Thailand) and Perlis (Malaysia). Working paper no. 433, The Hague: Institute of Social Studies.

Andriesse, E. 2008. Institutions and regional development in Southeast Asia. A comparative analysis of Satun (Thailand) and Perlis (Malaysia). Netherlands Geographical Studies no. 374, Utrecht: Royal Netherlands Geographical Society. http://igitur-archive.library.uu.n1/dissertations/2008-0604-200854/ UUindex.html, Accessed June 4, 2008.

Askew, M. 2006. Electoral politics in Southern Thailand. Bangkok: King Prajadhipok's Institute.

Auditor General 2006. Laporan Negeri Perlis. Putrajaya: Jabatan Audit Negara Malaysia.

Bain, P., Watson, A., Mulvey, G., Taylor, P., \& Gall, G. 2002. Taylorism, targets and the pursuit of quantity and quality by call centre management. New Technology, Work and Employment, 17: 170-185.

Bardhan, P. 2005. Scarcity, conflicts and cooperation. Essays in the political and institutional economics of development. Cambridge: MIT. 
Barlow, C. 1999. Institutions and economic change in Southeast Asia: The context of development from the 1960's to the 1990's. Cheltenham: Edward Elgar.

Bjerke, B. 2000. A typified, culture based, interpretation of management of SME's in Southeast Asia. Asia Pacific Journal of Management, 17(1): 103-132.

BOI 2007. Labour issues. http://www.boi.go.th/english/how/labor_issues_and_important_addresses.asp, Accessed April 2007.

Carney, M. 2004. The institutions of industrial restructuring in Southeast Asia. Asia Pacific Journal of Management, 21(1-2): 171-188.

Carney, M., \& Gedajlovic, E. 2001. Corporate governance and firm capabilities: A comparison of managerial, alliance and personal capitalisms. Asia Pacific Journal of Management, 18: 335-354.

Case, W. 2005. Malaysia: New reforms, old continuities, tense ambiguities. Journal of Development Studies, 41(2): 284-309.

Department of Fisheries 2005. Fisheries statistics of Thailand. Bangkok: Ministry of Agriculture and Cooperatives.

Department of Statistics. 1993/2005. State data bank. Putrajaya: Department of Statistics.

Doner, R., Ritchie, B., \& Slater, D. 2005. Systemic vulnerability and the origins of developmental states: Northeast and Southeast Asia in comparative perspective. International Organization, 59: 327-361.

EPU various years. Seventh (1996), Eighth (2001) and Ninth (2006) Malaysian Plan. Putrajaya: Economic Planning Unit.

FAO 2007. Fishtat Plus. http://faostat.fao.org/site/342/default.aspx, Accessed March 2007.

Gomez, E. 2002. Political business in Malaysia. Party factionalism, corporate development and economic crisis. In E. Gomez (Ed.). Political business in East Asia: 82-112. London: Routledge.

Gomez, E., \& Hsiao, H. 2003. Chinese business in Southeast Asia. London: Routledge Curzon.

Gomez, E., Loh, W. L., \& Lee, K. H. 2003. Malaysia. In E. Gomez \& H. Hsiao (Eds.). Chinese business in Southeast Asia: 62-84. London: Routledge Curzon.

Goss, J., Burch, D., \& Rickson, R. 2000. Agri-food restructuring and third world transnationals: Thailand, the CP Group and the global shrimp industry. World Development, 28(3): 513-530.

Haggard, S. 2004. Institutions and growth in East Asia. Studies in Comparative International Development, 38(4): 53-81.

Hall, P., \& Soskice, D. 2001. Varieties of capitalism: The institutional foundations of comparative advantage. Oxford: Oxford University Press.

Harriss, J., Hunter, J., \& Lewis, C. 1995. The new institutional economics and third world development. Oxford: Blackwell.

Hewison, K. 2001. Pathways to recovery: Bankers, business and nationalism in Thailand. SEARC working paper no. 1, Hong Kong: City University of Hong Kong.

Hewison, K. 2005. Neo-liberalism and domestic capital: The political outcomes of the economic crisis in Thailand. Journal of Development Studies, 41(2): 310-330.

Jayasuriya, K. 2003. Embedded mercantilism and open regionalism: The crisis of a regional political project. Third World Quarterly, 24(2): 339-355.

Jayasuriya, K. 2004. Embedded mercantilism and open regionalism: The crisis of a regional political project. In K. Jayasuriya (Ed.). Asian regional governance: 21-38. London: Routledge Curzon.

Jomo, K. 2003. M Way: Mahathir's economic legacy. Petaling Jaya: Forum.

Krongkaew, M. 1999. The economics of institutional change: Making economic policy in Thailand. In C. Barlow (Ed.). Institutions and economic change in Southeast Asia: The context of development from the 1960's to the 1990's: 85-104. Cheltenham: Edward Elgar Publishing.

Lane, D., \& Myant, M. (Eds.). 2007. Varieties of capitalism in post-communist countries. Basingstroke: Palgrave Macmillan.

Li, P. P. 2007. Guanxi as the personalized form of social capital: Toward a geocentric framework of formal-informal exchange. Paper presented at APJM special issue conference: "Varieties of Asian Capitalism: Indigenization and internationalization.” Brisbane: December 10-12.

Mackie, J. 2003. Thailand. In E. Gomez \& H. Hsiao (Eds.). Chinese business in Southeast Asia: 85-100. London: Routledge Curzon.

Mackie, J. 1999. Entrepreneurship and Institutions. In C. Barlow (Ed.). Institutions and economic change in Southeast Asia: The context of development from the 1960's to the 1990's: 72-84. Cheltenham: Edward Elgar Publishing.

McVey, R. (Ed.). 2000. Money and power in provincial Thailand. Honolulu: University of Hawaii Press. National Statistical Office (NSO) 2005. Changwat Satun. Bangkok: NSO.

NESDB 2007. Gross provincial product. http://www.nesdb.go.th/econSocial/macro/gpp_data/index.html, Accessed February 2007. 
Nelson, M. 2005. Analyzing provincial political structures in Thailand: Phuak, Trakun and Hua Kanaen. SEARC working paper no. 79, Hong Kong: City University of Hong Kong.

North, D. 1991. Institutions, institutional change and economic performance. Cambridge: Cambridge University Press.

Pananond, P., \& Zeithaml, C. 1998. The international expansion process of MNE's from developing countries: a case study of Thailand's CP group. Asia Pacific Journal of Management, 15(2): 163-184.

Pasuk, P., \& Baker, C. 2004. Thaksin: The business of politics in Thailand. Chang Mai: Silkworm Books.

Peng, M., \& Delios, A. 2006. What determines the scope of the firm over time and around the world? An Asia Pacific perspective. Asia Pacific Journal of Management, 23(4): 385-405.

Perry, M. 2003. Business networking and the changing industrial landscape. In L. S. Chia (Ed.). Southeast Asia transformed: A geography of change. Singapore: ISEAS.

Schamp, E. 2003. Raum, interaktion und institution. Anmerkungen zu drei Grundperspektiven der Deutschen wirtschaftgeographie. Zeitschrift für Wirtschaftsgeographie, 47(3-4): 145-158.

Schmidt, V. 2003. French capitalism transformed, yet still a third variety of capitalism. Economy and Society, 32(4): 526-554.

Shamsul, A. 1986. From British to bumiputra rule: Local politics and rural development in Peninsula Malaysia. Singapore: Institute of Southeast Asian Studies (reprint 2004).

Suehiro, A. 1989. Capital accumulation in Thailand 1855-1985. Chiang Mai: Silkworm Books.

Tickell, A., \& Peck, J. 1995. Social regulation after fordism: Regulation theory, neo-liberalism and the global-local nexus. Economy and Society, 24: 357-386.

Tipton, F. 2007. Managing under the guidance of a strong state. Capitalism in Southeast Asia. Paper presented at APJM Special Issue Conference: "Varieties of Asian Capitalism: Indigenization and Internationalization." Brisbane: December 10-12.

UNDP 2006. Human development report 2006. Beyond scarcity: Power, profit and the global water crisis. New York: Palgrave Macmillan.

UNDP 2007. Thailand human development report 2007. Sufficiency and Human Development. Bangkok: UNDP.

Weidenbaum, M., \& Hughes, S. 1996. The bamboo network: How expatriate Chinese entrepreneurs are creating a new economic superpower in Asia. New York: The Free Press.

White, N. 2004. The beginnings of crony capitalism: Business, politics and economic development in Malaysia. Modern Asian Studies, 38(2): 389-417.

Whitley, R. 1999. Divergent capitalisms. The social structuring and change of business systems. New York: Oxford University Press.

Wingfield, T. 2002. Democratisation and economic crisis in Thailand. Political business and the changing dynamics of the Thai state. In E. Gomez (Ed.). Political business in East Asia: 250-291. London: Routledge.

Yeung, H. 1999. The internationalization of ethnic Chinese business firms from Southeast Asia: Strategies, processes and competitive advantage. International Journal of Urban and Regional Research, 23(1): $88-102$.

Edo Andriesse ( $\mathrm{PhD}$, Utrecht University) was a $\mathrm{PhD}$ Candidate at International Development Studies, Utrecht University, The Netherlands, between September 2003 and November 2007. The research project was concerned with a comparative analysis of institutions and regional development at the Thailand/ Malaysia border. He now teaches economics at International College, Khon Kaen University in Thailand.

Guus van Westen (PhD, Utrecht University) is Assistant Professor at International Development Studies, Utrecht University, The Netherlands. He teaches a wide range of development and human geography courses. Furthermore, he conducts research and publishes on regional development in Southeast Asia and India. He was also editor of the internationally refereed journal TESG. 